\title{
THE US FISCAL MULTIPLIER AND INCOME-DRIVEN TAXES AND IMPORTS
}

\author{
DOI: 10.17261/Pressacademia.2021.1460 \\ JBEF-V.10-ISS.4-2021(1)-p.148-156
}

Samih Antoine Azar

Haigazian University, Faculty of Business Administration \& Economics, Mexique Street, Kantari, Beirut, Lebanon. samih.azar@haigazian.edu.Ib , ORCID: 0000-0003-4111-797X

\begin{tabular}{l}
\hline Date Received: November 1, $2021 \quad$ Date Accepted: December 20, 2021 \\
\hline To cite this document \\
Azar, S.A., (2021). The US fiscal multiplier and income-driven taxes and imports. Journal of Business, Economics and Finance (JBEF), 10(4), 148- \\
156. \\
Permanent link to this document: $\underline{\text { http://doi.org/10.17261/Pressacademia. } 2021.1460}$ \\
Copyright: Published by PressAcademia and limited licensed re-use rights only.
\end{tabular}

\section{ABSTRACT}

Purpose - This paper aims to develop an equation for the government budget multiplier that does not require the input of the marginal propensity to consume. In parallel, the paper computes from this equation the actual value of the budget multiplier for the US.

Methodology - The paper starts from the premise that taxes and imports are income-driven, and that the level of investment is equal to the level of saving. This leads to a theoretical model that is characterized solely by two parameters: the marginal income tax rate, and the marginal propensity to import. Noteworthy the marginal propensity to consume does not appear in the equation. Subsequently, the paper estimates the empirical marginal income tax rate by regression analysis, and the marginal propensity to import by relying on general import demand functions, the latter in order to avoid having an omitted variable bias with a simple linear regression.

Findings - The paper finds that the theoretical balanced budget multiplier is nil while the straight multiplier is demonstrated to be equal to the ratio of the sum of the marginal income tax rate to the marginal propensity to consume. The analysis shows that the US multiplier is estimated to be between 2.27 and 3.20, depending upon the empirical results.

Conclusion - The paper concludes that the marginal propensity to consume is not needed for identifying the government multiplier. Only the marginal tax rate and the marginal propensity to import are needed. And although the balanced budget multiplier is demonstrated theoretically to be zero, the straight fiscal multiplier is found to be higher than the usual in classic models, but more in line with the recent empirical findings. Governments have therefore a powerful policy tool, and investment in infrastructure and in scientific research are forecast to be unequivocally effective. At the very least, this is true unmistakably in theory.

Keywords: Fiscal multiplier, balanced budget multiplier, marginal propensity to import, marginal income tax rate, USA JEL Codes: E62, F41

\section{INTRODUCTION}

Public authorities have a panoply of policies to enhance the well-being of their people. Among these is fiscal policy, which is one of the most visible and widely scrutinized policy. Governments choose the size and composition of their expenditures, and conduct the imposition and collection of taxes. For macroeconomists fiscal policy is understood to consist of affecting final output by controlling the level of government spending or taxes. The inherent notion is that a given change in spending (taxation) propels (reduces) aggregate income. The relation is described by a multiplier effect, which means that the national aggregates change by a multiple of the change in spending. By definition a multiplier is a figure higher than 1 , and this is a condition for success for fiscal policy, and determines the extent of its effectiveness. If the multiplier is higher than 1 spending on public works and infrastructure, or on any other similar stimuli, are worthwhile, and will spur growth. The question, which is addressed in this paper, is how much is the US fiscal multiplier? A related question is how can this multiplier be measured without resorting to the marginal propensity to consume (MPC)? Is there an alternative method to the use of the MPC? Finally, what is the magnitude of the balanced budget multiplier, or the actual impact from additional spending, occurring with an equal amount of additional income or distortionary taxes. Answers to these questions will be proposed.

In the second section, the paper lists some of the literature on the topic. There are 3 parts: a survey of the literature on the multiplier, a survey of empirical import demand functions, and an account of the Lebanese experience. In section 3 , a 
theoretical model for the multiplier, that is characterized by the absence of the marginal propensity to consume (MPC), but to depend on the marginal tax rate $(t)$, and the marginal propensity to import $(\mathrm{m})$. What is left to do is estimating the two parameters $t$ and $m$. This is done in the following section, section 4 . Subsection 4.1 is for $t$, and subsection 2 is for $m$. Section 4 ends with the computation of the US fiscal multiplier implied by the theoretical model developed in section 3 . Section 5 is the conclusion.

\section{LITERATURE SURVEY}

A brief purview of the literature on the spending multiplier, that has appeared in the last decade, is offered now. On the theoretical front, Christiano et al. (2011) have argued, by using a new Keynesian model, that the government spending multiplier is "large" when there is a zero lower bound on the nominal interest rate. Empirically, Qazizada and Stockhammer (2015) have disputed this fact. However, they find that the multipliers are much higher in contraction episodes, relative to expansion ones. They ascribe that to a Keynesian legacy. Owyang et al. (2013) have surprisingly not reported a differential multiplier for periods of high unemployment or slack in the economy. By contrast, Gabriel et al. (2020) have studied the Eurozone, and they concluded from their sample that the multiplier is between 1.9 and 2.9 and that it indeed larger in recessions. Bernardini et al. (2020) concur with this proposition, and they state that the multiplier can reach 4, in times of recession. Evidence that a higher level of private nonfinancial debt produces greater multipliers is presented in Bernardini and Peersman (2018). And Fritsche et al. (2021) document that the multiplier is relatively small for economies witnessing high volatility.

Table 1 lists a series of research papers on the subject of the marginal propensity to import. The intent of the literature was in fitting an import demand function. However, a byproduct of this is an estimate of $\mathrm{m}$. If $\mathrm{m}$ needs to be evaluated the ceteris paribus condition must prevail and all variables that determine imports should be considered. This explains why in this paper no disaggregate regressions of expenditures are utilized because it becomes difficult to retrieve a value for $m$. The explanatory variables for the import demand function, from which the marginal propensity to import $(\mathrm{m})$ is estimated, are GDP, DEF (GDP deflator), and IMPDEF (imports price index). To this list is added the variable TAX. See Table 1 for some of the literature. It is noticeable that there are papers on almost total countries.

As an introduction to the empirics a related research paper applied to Lebanon is summarized (Azar, 2021a). To ensure the robustness of the results 8 different econometric procedures were applied in this study. The two crucial models are the regressions of taxes and imports over aggregate output. The slopes of these models are the estimates of $t$ and $m$. The paper lists estimates from annual and monthly samples. What is remarkable in the estimates is the statistical precision of the two parameters. Whatever the sample frequency, whatever the size of the samples, and whatever the econometric procedure the results come very close. With annual samples the marginal propensity to tax is between 0.1545 and 0.1714 , and the marginal propensity to import is between 0.5038 and 0.5217 . These ranges are small, exact, and reasonable, because Lebanon experiences a relatively low proportion of income taxes and is a highly open economy. The implied spending multiplier is between 1.411 and 1.519 , and has an average of 1.470 . With monthly samples the marginal propensity to tax is between 0.1651 and 0.1816, and the marginal propensity to import is between 0.4572 and 0.4755 . Again these ranges are small, exact, and reasonable. The implied spending multiplier is between 1.542 and 1.594, and is on average 1.561. Overall the grand average is 1.515 .

Table 1: Some Literature on Import Demand

\begin{tabular}{|c|c|c|c|c|}
\hline Author(s) & Variables & Country & Econometric procedure & Elasticities \\
\hline $\begin{array}{l}\text { Arize \& Walker } \\
\text { (1992) }\end{array}$ & $P^{f}, P^{d}, Y, E$ & Japan & $\begin{array}{l}\text { Engle-Granger 2-step } \\
\text { test }\end{array}$ & $1.22,1.306,1.17,0.988,-0.50,-.33$ \\
\hline $\begin{array}{l}\text { Doroodian et al. } \\
\text { (1994) }\end{array}$ & $P^{f} / P^{d}, Y$ & KSA & $\begin{array}{l}\text { Lag of dependent } \\
\text { variable }\end{array}$ & $0.47,2.86,-1.45$ \\
\hline $\begin{array}{l}\text { Dutta \& Ahmed } \\
\text { (1999) }\end{array}$ & $P^{f} / P^{d}, Y, R$ & Bangladesh & ECM UECM & $1.63,2.58$ \\
\hline Tang \& Nair (2002) & $P^{f} / P^{d}, Y$ & Malaysia & $\begin{array}{l}\text { Cointegration \& Bounds } \\
\text { test }\end{array}$ & $1.267,1.06$ \\
\hline $\begin{array}{l}\text { Matsubayashi \& } \\
\text { Hamori (2003) }\end{array}$ & $P^{f} / P^{d}, Y$ & G7 & $\begin{array}{l}\text { Engle-Granger 2-step } \\
\text { test }\end{array}$ & None \\
\hline Tang (2004) & & ASEAN-5 & Cointegration & None \\
\hline $\begin{array}{l}\text { Islam \& Hassan } \\
\text { (2004) }\end{array}$ & $P^{f} / P^{d}, Y, R / Y$ & Bangladesh & $\begin{array}{l}\text { Cointegration } \\
\text { Johanssen \& Juselius }\end{array}$ & $1.833,0.542,-0.401$ \\
\hline
\end{tabular}




\begin{tabular}{|c|c|c|c|c|}
\hline $\begin{array}{l}\text { Tsionas \& } \\
\text { Christopoulos (2004) }\end{array}$ & $P^{f} / P^{d}, Y$ & 5 industrials & DOLS, FM & $0.98-2.43,0.07-1.54$ \\
\hline $\begin{array}{l}\text { Narayan \& Narayan } \\
\text { (2005) }\end{array}$ & $P^{f} / P^{d}, Y$ & Fiji & $\begin{array}{l}\text { ARDL, DOLS, \& Bounds } \\
\text { test }\end{array}$ & $1.89-1.85,0.07-1.54$ \\
\hline Chang et al. (2005) & $P^{f} / P^{d}, Y$ & South Korea & Bounds test \& ECM & $1.86,0.20$ \\
\hline Kalyoncu, (2006) & $P^{f} / P^{d}, Y$ & Turkey & Cointegration, ECM & $-0.88,1.07$ \\
\hline $\begin{array}{l}\text { Katsimi \& Moutos } \\
\text { (2006) }\end{array}$ & $P^{f} / P^{d}, Y, R E E R$ & US & Cointegration & $1.98,-0.35$ \\
\hline $\begin{array}{l}\text { Ozturk and Acaravci } \\
\text { (2009) }\end{array}$ & $P^{f} / P^{d}, Y$ & $\begin{array}{l}\text { Latin } \\
\text { America \& } \\
\text { Caribeans } \\
\end{array}$ & Panel cointegration & $\begin{array}{l}1.38 \\
-0.7\end{array}$ \\
\hline Emran \& Shilpi (2010) & $P^{f} / P^{d}, C$ & $\begin{array}{l}\text { India } \\
\text { Sri Lanka }\end{array}$ & ARDL & \\
\hline Chani et al. (2011) & $P^{f} / P^{d}, C, I, X$ & Pakistan & Johansen \& Juselius & $2.67,-0.14$ \\
\hline Yin \& Hamori (2011) & $P^{f} / P^{d}, Y$ & China & ARDL & $1.524-2.661,0.34-0.397$ \\
\hline Hibbert et al. (2012) & $P^{f} / P^{d}, Y, R, V$ & Jamaica & Cointegration, ECM & $0.68-5.8,0.93-2.4$ \\
\hline $\begin{array}{l}\text { Doroodian et al. } \\
(2015)\end{array}$ & $P^{f}, P^{d}, C, I, X$ & Turkey & ARDL Bounds test & -0.065 \\
\hline Hor et al. (2018) & $P^{f} / P^{d}, C, I, X, E$ & Cambodia & ARDL & -0.252 \\
\hline Yoon \& Kim (2019) & $P^{f}, P^{d}, C, I, X, G$ & US & $\begin{array}{l}\text { Cointegration, ECM, \& } \\
\text { Johansen Juselius }\end{array}$ & $0.91,0.28$ \\
\hline $\begin{array}{l}\text { Katuria \& Kumar } \\
\text { (2021) }\end{array}$ & $P^{f} / P^{d}, C, I, X, E$ & India & $\begin{array}{l}\text { Non-linear ARDL } \\
\text { Bounds test \& } \\
\text { cointegtaion }\end{array}$ & $0.77-1.78,0.2-0.286$ \\
\hline
\end{tabular}

\section{THE MODEL}

The usual macroeconomic accounting identity is stated as:

$$
Y \equiv C+I+G+X-M
$$

Where $Y$ is output, $C$ consumption, I investment, $G$ government spending, $X$ exports and $M$ imports. The levels of $G$ and $X$ are considered autonomous and exogenous. The behavior of the household is to choose consumption out of the amount of disposable income. If $t$ is the income tax rate, then total taxes are $t Y$. Hence:

$$
C=c_{o}+c(Y-t Y)
$$

where $\mathrm{c}$ is the marginal propensity to consume and is less than 1 , and $c_{0}$ is autonomous consumption. In this model, investment equals saving:

$$
I=S
$$

And saving is described by the following behavioral function out of disposable income, given that what is not consumed is saved.

$$
S=s_{o}+s(Y-t Y)=s_{o}+(1-c)(Y-t Y)
$$

Also it is assumed that output $\mathrm{Y}$ drives imports:

$$
M=m_{o}+m Y
$$

With $m$ being the marginal propensity to import. Replacing all the above equations (2), (3), (4), and (5) inside the first identity (1) one obtains the following equilibrium relation:

$$
Y=\alpha_{o}+c(1-t) Y+(1-c)(1-t) Y+G+X-m Y
$$

Where $\alpha_{o}$ is total net autonomous spending. Moving the terms in $Y$ in equation (6) to the left hand side of the equation, and solving for $Y$, then one finds: 


$$
Y=\frac{a_{o}+G+X}{1-c(1-t)-(1-c)(1-t)+m}=\frac{a_{o}+G+X}{t+m}
$$

The spending multiplier is hence $1 /(t+m)$, which is the inverse of the sum of the marginal propensities to tax and to import. This multiplier applies also to autonomous exports $X$, and to other autonomous expenditures. If exports go up, then the economy will grow by the same multiple. This result does not necessitate the measurement of the marginal propensity to consume c, which is usually difficult to measure.

Using equation (7) one can solve for the balanced budget multiplier where the additional government spending is covered by additional taxes. Hence $t$ is made higher. First, the full derivative of equation (7) with respect to the tax rate $t$ and to government spending $\mathrm{G}$ is made equal to:

$$
\Delta Y=-\frac{a_{o}+G+X}{(t+m)^{2}} \Delta t+\frac{1}{(t+m)} \Delta G=-\frac{Y}{(t+m)} \Delta t+\frac{1}{(t+m)} \Delta G=-\frac{Y \Delta t}{(t+m)}+\frac{1}{(t+m)} \Delta G
$$

If the budget is balanced, then the change in spending is equal to the change in taxes:

$$
\Delta G=\Delta t Y=Y \Delta t+t \Delta Y \Rightarrow Y \Delta t=\Delta G-t \Delta Y
$$

Replacing the last term of equation (9) into (8) the balanced budget multiplier becomes as follows and is found to be equal to zero:

$$
\begin{aligned}
& \Delta Y=-\frac{1}{(t+m)}(\Delta G-t \Delta Y)+\frac{1}{(t+m)} \Delta G=\frac{1}{t+m} t \Delta Y \\
& \Delta Y-\frac{1}{t+m} t \Delta Y=\Delta Y\left(1-\frac{t}{t+m}\right)=0 \text { which implies that } \Delta Y=0
\end{aligned}
$$

In the literature the fiscal multiplier is calculated as follows, with the same model except that equation ( 3 ) is not imposed:

$$
Y=\frac{a_{o}+G+X}{1-(1-t) c+m}
$$

which is equivalent to equation (7) if c=1. In fact, c is very close to 1 , and has been estimated lately at around 0.918605 (Azar, 2021b).

\section{THE EMPIRICAL RESULTS}

Real tax receipts (TAX), real GDP (GDP), real imports (IMP), real government expenditures (GOV), the level of market stock prices (STOCK), and the ratio of the GDP deflator on the imports price index fail all Phillips-Perron stationarity tests in levels but are stationary in first differences. These data are quarterly and vary between 1947Q1 to 2021Q2, with 296 observations, except STOCK which is available from 1960Q1 to 2021Q2, with 246 observations, and the series are all retrieved from the web page of the Federal Reserve Bank of Saint Louis (FRED).

\subsection{Estimating the Tax Rate $t$}

Since the purpose is to measure the marginal tax rate, or the marginal propensity to tax out of income, the first candidate to be an explanatory variable is GDP. The selected control variables are imports (IMP), government spending (GOV), and the stock market (STOCK). The relation between these four explanatory variables against the amount of tax receipts is estimated by the ARDL method (Auto Regressive Distributed Lag). The F-bounds test has a value of 7.270 , well above the critical value at $1 \%$ of 4.787 for a finite sample of 80 . Therefore, the five variables are co-integrated. The slope of the long run estimate of the marginal tax rate is 0.2324 . There is no short run estimate. Other results are in Tables 2 and 3.

There are no short run estimates for GOV, and for STOCK (Table 3). As for the short run slopes on the current IMP variable (0.3027) and its quarterly lag (0.1488) they sum up to 0.4515 (Table 4). The long run effect of IMP on TAX is -0.3510 , that for GOV is -4.5146, and for STOCK is 6.2559 (Table 3). It is unclear why the two long run slope estimates on IMP and GOV are negative. One can say that the higher are imports, the lower is output, and hence the lower are income taxes. Similarly, the higher is public spending, the higher are interest rates, the lower is consumption and investment, the lower is aggregate output, and the lower are income taxes. This is referred to as a crowding-out. The impact of STOCK measures a wealth effect, and is understandably positive. All four variables enter the long run regression with statistical significance with the highest $p$-value at 0.0040 (Table 3). The speed of adjustment to the long run takes around 1.16 years, which denotes a fast speed.

There is evidence of a break in the GDP series. The Quandt-Andrews unknown breakpoint test for a $15 \%$ trimming indicates a significant break on 1994Q1. The test involved 239 comparisons. A categorical variable is constructed that takes the value 1 from 1947Q1 till 1993Q4, and zero otherwise. This variable is multiplied interactively with GDP, producing two interactive 
variables on GDP, and the same regression is re-estimated. The results (Tables 4, and 5) are very close to the previous evidence in Tables 2 \& 3.

Table 2: Co-Integration and Long-Run Regression of TAX on GDP, IMP, STOCK and GOV by ARDL Estimation

\begin{tabular}{lcccc} 
Variable & Coefficient & Std. Error & t-Statistic & Prob. \\
\hline \hline GDP & 0.232422 & 0.015129 & 15.36290 & 0.0000 \\
IMP & -0.350961 & 0.126629 & -2.771570 & 0.0060 \\
STOCK & 6.255912 & 2.214364 & 2.825150 & 0.0051 \\
GOV & -4.514573 & 1.522088 & -2.966039 & 0.0033 \\
C & -91.80539 & 72.33138 & -1.269233 & 0.2056
\end{tabular}

Table 3: Error-Correction (EC) Model of the Regression in Table 1 by ARDL Estimation

\begin{tabular}{|c|c|c|c|c|}
\hline Variable & Coefficient & Std. Error & t-Statistic & Prob. \\
\hline C & -19.74301 & 4.438523 & -4.448104 & 0.0000 \\
\hline $\mathrm{D}(\operatorname{TAX}(-1))$ & -0.097979 & 0.059556 & -1.645169 & 0.1013 \\
\hline $\mathrm{D}(\operatorname{TAX}(-2))$ & 0.233503 & 0.050670 & 4.608303 & 0.0000 \\
\hline $\mathrm{D}(\operatorname{TAX}(-3))$ & 0.188044 & 0.052385 & 3.589670 & 0.0004 \\
\hline $\mathrm{D}(\mathrm{IMP})$ & 0.302698 & 0.051675 & 5.857753 & 0.0000 \\
\hline $\mathrm{D}(\mathrm{IMP}(-1))$ & 0.148762 & 0.053038 & 2.804835 & 0.0055 \\
\hline $\mathrm{EC}(-1)$ & -0.215053 & 0.032517 & -6.613528 & 0.0000 \\
\hline R-squared & 0.423235 & \multicolumn{2}{|c|}{ Mean dependent variable } & 12.15505 \\
\hline Adjusted R-squared & 0.408756 & \multicolumn{2}{|c|}{ S.D. dependent variable } & 54.67141 \\
\hline S.E. of regression & 42.03815 & \multicolumn{2}{|c|}{ Akaike info criterion } & 10.34307 \\
\hline $\begin{array}{l}\text { Sum squared } \\
\text { residual }\end{array}$ & 422362.3 & \multicolumn{2}{|c|}{ Schwarz criterion } & 10.44282 \\
\hline Log likelihood & -1265.198 & \multirow{2}{*}{\multicolumn{2}{|c|}{$\begin{array}{c}\text { Hannan-Quinn criterion } \\
\text { Durbin-Watson stat }\end{array}$}} & 10.38324 \\
\hline F-statistic & 29.23009 & & & 2.053651 \\
\hline Prob. (F-statistic) & 0.000000 & & & \\
\hline
\end{tabular}

Table 4: Co-integration and long run regression of TAX on GDP, IMP, STOCK, and GOV, by ARDL Estimation, including interactive dummies (DUM)

\begin{tabular}{|c|c|c|c|c|}
\hline Variable & Coefficient & Std. Error & t-Statistic & Prob. \\
\hline GDP*DUM & 0.237573 & 0.015735 & 15.09802 & 0.0000 \\
\hline GDP*(1-DUM) & 0.232306 & 0.014691 & 15.81232 & 0.0000 \\
\hline IMP & -0.382551 & 0.128794 & -2.970246 & 0.0033 \\
\hline STOCK & 6.211408 & 2.149069 & 2.890278 & 0.0042 \\
\hline GOV & -4.559965 & 1.477361 & -3.086561 & 0.0023 \\
\hline C & -81.20887 & 71.11336 & -1.141964 & 0.2546 \\
\hline R-squared & 0.425260 & \multicolumn{2}{|c|}{ Mean dependent variable } & 12.15505 \\
\hline Adjusted R-squared & 0.410831 & \multicolumn{2}{|c|}{ S.D. dependent variable } & 54.67141 \\
\hline S.E. of regression & 41.96431 & \multicolumn{2}{|c|}{ Akaike info criterion } & 10.33956 \\
\hline Sum squared residual & 420879.7 & \multicolumn{2}{|c|}{ Schwarz criterion } & 10.43930 \\
\hline Log likelihood & -1264.766 & \multicolumn{2}{|c|}{ Hannan-Quinn criterion } & 10.37972 \\
\hline F-statistic & 29.47337 & \multirow{2}{*}{\multicolumn{2}{|c|}{ Durbin-Watson stat }} & 2.055506 \\
\hline Prob. (F-statistic) & 0.000000 & & & \\
\hline
\end{tabular}


The relation between these five explanatory variables is estimated by replacing GDP with the two interactive GDP variables, which are defined with the categorical variable, against the amount of tax receipts and the whole system is estimated by ARDL (Auto Regressive Distributed Lag). The F-bounds test has a value of 6.3443 , with a critical value of 4.587 at the $1 \%$ marginal significance level. The marginal tax rate is 0.2376 before $1994 Q 1$ and 0.2323 after. There is no short run estimate. Other results are in Tables 4 and 5. There are no short run estimates for GOV, and STOCK (Table 5). As for the short run slopes on the current IMP variable (0.2897) and its quarterly lag (0.1475) they sum up to 0.4372 (Table 5). The long run effect of IMP on TAX is 0.3826 , that for GOV is -4.5600 , and for STOCK is 6.2114 (Table 4). It is unclear why the two long run slope estimates on IMP and GOV are negative, but can be rationalized as above. However, all five variables enter the long run regression with statistical significance with the highest $p$-value at 0.0020 (Table 4). The speed of adjustment to the long run takes around 1.129 years, which denotes a fast speed.

Table 5: Error-Correction (EC) Model of the Regression in Table 4 by ARDL Estimation

\begin{tabular}{lcccc} 
Variable & Coefficient & Std. Error & t-Statistic & Prob. \\
\hline \hline C & -17.99067 & 4.214700 & -4.268553 & 0.0000 \\
D(TAX(-1)) & -0.094430 & 0.059535 & -1.586133 & 0.1141 \\
D(TAX(-2)) & 0.234988 & 0.050604 & 4.643617 & 0.0000 \\
D(TAX(-3)) & 0.189010 & 0.052301 & 3.613906 & 0.0004 \\
D(IMP) & 0.289737 & 0.052412 & 5.528029 & 0.0000 \\
D(IMP(-1)) & 0.147431 & 0.052951 & 2.784302 & 0.0058 \\
EC(-1) & -0.221536 & 0.033122 & -6.688404 & 0.0000 \\
\hline \hline
\end{tabular}

\subsection{Estimating the Marginal Propensity to Import $(\mathrm{m})$}

Table 1 lists a series of research papers on the subject of the marginal propensity to import. The intent of the literature was in fitting an import demand function. However, a byproduct of this is an estimate of $\mathrm{m}$. If $\mathrm{m}$ needs to be evaluated the ceteris paribus condition must prevail and all variables that determine imports should be considered. This explains why in this paper no disaggregate regressions of expenditures are utilized because it becomes difficult to retrieve a value for $m$. The explanatory variables for the import demand function, from which the marginal propensity to import $(\mathrm{m})$ is estimated, are GDP, DEF (GDP deflator), and IMPDEF (imports price index). To this list is added the variable TAX. See Table 1 for some of the literature. It is noticeable that there are papers on almost total countries.

In the literature the TAX variable is omitted. A linear relation is postulated. The regression's co-integration test, with variables in levels, do not support co-integration. Therefore, the regression was estimated with first differences of the variables. It is expected that the coefficient on $\triangle G D P$ is an estimate of the marginal propensity to import (m), and is positive with a value between 0 and 1 . The coefficient on $\triangle D E F$ is expected to be positive because local consumer goods are substitutes to imports, and the coefficient on $\triangle I M P D E F$ is negative, because of an own price effect. The coefficient on $\triangle T A X$ is found to be positive, for no obvious reason. Higher taxes reduce GDP, which reduces imports. Therefore, the relation is negative. Moreover, higher taxes reduce interest rates, which induces a capital outflow, and a depreciation of the dollar, and this leads to encourage exports, and discourage imports, and the relation is still negative. However, because of the crowding-in effect of lower interest rates, investment is higher, leading to an increase in GDP and consequently in imports, and the relation is positive. It seems that the net effect is a positive relation. The regression results, by applying robust least squares, are in Table 7 . The signs of all three variables, $\triangle \mathrm{GDP}, \triangle \mathrm{DEF}$, and $\triangle \mathrm{IMPDEF}$, are according to expectations. The marginal propensity to import $(\mathrm{m})$ is estimated to be 0.09689 , an estimate which denotes that the US is relatively a closed economy. All coefficients are statistically highly significant with a p-value less than 0.00005 .

Table 7: Robust Least Squares of real imports as a function of GDP, TAX, DEF, and IMPDEF (All variables are in first differences)

\begin{tabular}{lcccc} 
Variable & Coefficient & Std. Error & z-Statistic & Prob. \\
\hline \hline C & -2.015106 & 1.121729 & -1.796429 & 0.0724 \\
D(GDP) & 0.096892 & 0.004844 & 20.00279 & 0.0000 \\
D(TAX(-1)) & 0.131988 & 0.013375 & 9.868179 & 0.0000 \\
D(DEF) & 17.08119 & 2.736884 & 6.241108 & 0.0000 \\
D(IMPDEF) & -5.872272 & 0.426743 & -13.76066 & 0.0000
\end{tabular}




\begin{tabular}{llll}
\hline \hline \multicolumn{4}{c}{ Robust Statistics } \\
\hline \hline R-squared & $\begin{array}{l}0.228107 \\
13.21473\end{array}$ & $\begin{array}{c}\text { Adjusted R-squared } \\
\text { Deviance }\end{array}$ & $\begin{array}{l}0.217497 \\
174.6290 \\
\text { Scale }\end{array}$ \\
Rn-squared statistic & 699.9081 & Prob. (Rn-squared stat.) & 0.000000 \\
\hline \hline \multicolumn{4}{l}{ Non-robust Statistics } \\
\hline \hline Mean dependent variable & 11.77068 & S.D. dependent variable & 54.33318 \\
S.E. of regression & 44.72904 & Sum squared residual & 582199.8 \\
\hline
\end{tabular}

When the same regression is estimated by replacing GDP with the two interactive GDP variables, which are defined with the same categorical variable as above, the results are in Table 8. Two estimates of the marginal propensity to import are obtained. The first one for the period before 1994Q1, and which equals 0.08035 . The second is for the period after 1994Q1, and which is 0.20971 . It seems that the US has witnessed a gradual increase in trade and openness. All other coefficients have the correct expected sign, and are highly statistically significant, with the smallest $p$-value being less than 0.00005 .

Table 8: Robust Least Squares of Real Imports of the Regression in Table 5, including interactive dummies (DUM)

\begin{tabular}{lcccc} 
Variable & Coefficient & Std. Error & z-Statistic & Prob. \\
\hline \hline C & -1.514483 & 1.162575 & -1.302697 & 0.1927 \\
D(GDP)*DUM & 0.210169 & 0.004783 & 43.94136 & 0.0000 \\
D(GDP)*(1-DUM) & 0.082116 & 0.013705 & 5.991598 & 0.0000 \\
D(TAX(-1)) & 0.068471 & 0.012845 & 5.330475 & 0.0000 \\
D(DEF) & 16.18804 & 2.654213 & 6.098996 & 0.0000 \\
D(IMPDEF) & -4.766585 & 0.409322 & -11.64507 & 0.0000 \\
\hline \hline
\end{tabular}

\begin{tabular}{llcl}
\hline \hline \multicolumn{4}{c}{ Robust Statistics } \\
\hline \hline R-squared & 0.269024 & Adjusted R-squared & 0.256421 \\
Scale & 12.55752 & Deviance & 157.6914 \\
Rn-squared statistic & 2337.076 & Prob. (Rn-squared stat.) & 0.000000 \\
\hline \hline \multicolumn{4}{l}{ Non-robust Statistics } \\
\hline \hline Mean dependent variable & 11.77068 & S.D. dependent variable & 54.33318 \\
S.E. of regression & 33.06920 & Sum squared residual & 317135.9
\end{tabular}

\subsection{Estimates of the US Fiscal Multiplier}

The estimate of the tax rate in the previous subsection 4.2 is close to 0.23 . The estimate of the marginal propensity to import is on average $\mathbf{0 . 0 9 7}$, but is lower at 0.0804 for the period before 1994Q1, and is higher at 0.210 for the following period. Therefore, there are three estimates for the sum $\mathrm{t}+\mathrm{m}$. These are 0.327 on average, 0.314 for the period before 1994Q1, and 0.440 for the period after 1994Q1. The implied government spending multipliers are: $3.054,3.185$, and 2.273 . The latter figure is low because of a higher amount of import leakage. These figures are compared against the multiplier that includes the MPC. The latter is based on the following equilibrium equation (Equation (12)), and is repeated here:

$$
Y=\frac{a_{o}+G+X}{1-(1-t) c+m}
$$

The three estimates are: $1.614,1.648$, and 1.365 , which are substantially lower than the estimates in this paper. It is as if the multiplier in the literature is understated. 


\section{CONCLUSION}

This paper attempts to develop an alternative derivation of the government budget multiplier, and to provide for estimates for the US. The paper has two parts. Both parts are about the fiscal budget. The first part is theoretical and aims to find a fiscal multiplier that does not depend on the marginal propensity to consume, and the second part is empirical, through estimating the multiplier for the US. The theory revolves on the equality between saving and investment, starts from the premise of income-driven income taxes and imports, and produces the fiscal multiplier without resorting to the marginal propensity to consume. The empirics delve on estimating, for the US, the two crucial parameters in the model's formula, which are the marginal income tax rate and the marginal propensity to import. The multiplier equals the ratio of the sum. On the negative side the model predicts a zero figure for the balanced budget multiplier. In the statistical literature a low such multiplier is the norm, which means that a zero figure is not preposterous. However, the paper delivers a multiplier that is higher than what is usually specified, and stands at around 3, and maybe less, but no less than 2. Government investment in infrastructure and in research activities are deemed to be quite worthwhile at least theoretically. An avenue for future research is to apply the paper's model to other countries, both developed and developing. In this way the model will be more vindicated. One limitation to all studies of fiscal multipliers is that the actual multiplier is difficult to gauge because of policy, implementation, and political lags, and because there is no way to disentangle the effect of the government expenditures from other economy-wide shocks that occur simultaneously in the interim. Maybe it is for this reason that the estimated multiplier in some of the literature is way below the predicted value in this paper. However, recent applied research, especially during and after the zero lower bound of nominal interest rates, has found even higher multiplier than the one in this paper.

\section{REFERENCES}

Arize, A. C., \& Walker, J. (1992). A reexamination of Japan's aggregate import demand function: an application of the Engle and Granger twostep procedure. International Economic Journal, 6(2), 41-55.

Azar, S. A. (2021a). A simple and indirect approach to estimating the government spending multiplier for Lebanon, Lebanon Briefs, Blominvest, $1-6$.

Azar, S. A. (2021b). Measuring the US marginal propensity to consume. Economics Bulletin, 41(2), 283-292.

Bernardini, M., De Schryder, S., \& Peersman, G. (2020). Heterogeneous government spending multipliers in the era surrounding the great recession. Review of Economics and Statistics, 102(2), 304-322.

Bernardini, M., \& Peersman, G. (2018). Private debt overhang and the government spending multiplier: Evidence for the United States. Journal of Applied Econometrics, 33(4), 485-508.

Chang, T., Ho, Y. H., \& Huang, C. J. (2005). A reexamination of South Korea's aggregate import demand function: The bounds test analysis. Journal of Economic Development, 30(1), 119.

Chani, M. I., Pervaiz, Z., \& Chaudhary, A. R. (2011). Determination of Import Demand in Pakistan: The Role of Expenditure Components. Theoretical \& applied economics, 18(8), 345-366.

Christiano, L., Eichenbaum, M., \& Rebelo, S. (2011). When is the government spending multiplier large? Journal of Political Economy, 119(1), 78121.

Doroodian, K., Koshal, R. K., \& Al-Muhanna, S. (1994). An examination of the traditional aggregate import demand function for Saudi Arabia. Applied Economics, 26(9), 909-915.

Doroodian, K., Koshal, R. K., \& Al-Durmaz, N., \& Lee, J. (2015). An empirical analysis of import demand function for Turkey: An ARDL bounds testing approach. The Journal of Developing Areas, 49, 4, 215-226,

Dutta, D., \& Ahmed, N. (1999). An aggregate import demand function for Bangladesh: a cointegration approach. Applied Economics, 31(4), 465472.

Emran, M. S., \& Shilpi, F. (2010). Estimating an import demand function in developing countries: A structural econometric approach with applications to India and Sri Lanka. Review of International Economics, 18(2), 307-319.

Fritsche, J. P., Klein, M., \& Rieth, M. (2021). Government spending multipliers in (un) certain times. Journal of Public Economics, $203,104513$. Available at https://doi.org/10.1016/j.jpubeco.2021.104513.

Gabriel, R., Klein, M. and Pessoa, A. (2020) : The effects of government spending in the Eurozone, Sveriges Riksbank Working Paper Series, No. 400, Sveriges Riksbank, Stockholm.

Hibbert, K., Thaver, R. L., \& Hutchinson, M. C. (2012). An econometric analysis of Jamaica's import demand function with the US and UK. The International Journal of Business and Finance Research, 6(1), 109-120. 
Hor, C., Keo, K., \& Suttiprapa, C. (2018). An empirical analysis of Cambodia's import demand function. Journal of Management, Economics, and Industrial Organization, 2(1), 1-12.

Islam, A. M., \& Kabir Hassan, M. (2004). An econometric estimation of the aggregate import demand function for Bangladesh: Some further results. Applied Economics Letters, 11(9), 575-580.

Kalyoncu, H. (2006). An aggregate import demand function for Turkey: a cointegration analysis. Available at https://mpra.ub.uni-muenchen.de /4260/.

Kathuria, K., \& Kumar, N. (2021). An Empirical Investigation of the Disaggregated Import Demand Function: Non-linear ARDL Framework. Foreign Trade Review, 56(2), 197-205.

Katsimi, M., and Moutos, T. (2006). Inequality and the US import demand function, CESifo Working Paper, No. 1827, Center for Economic Studies and ifo Institute (CESifo), Munich.

Matsubayashi, Y., \& Hamori, S. (2003). Some international evidence on the stability of aggregate import demand function. Applied Economics, 35(13), 1497-1504.

Narayan, P. K., \& Narayan, S. (2005). Estimating income and price elasticities of imports for Fiji in a cointegration framework. Economic Modelling, 22(3), 423-438.

Owyang, M. T., Ramey, V. A., \& Zubairy, S. (2013). Are government spending multipliers greater during periods of slack? Evidence from twentieth-century historical data. American Economic Review, 103(3), 129-34.

Ozturk, I., \& Acaravci, A. (2009). An aggregate import demand function: An empirical investigation by panel data for Latin American and Caribbean countries. IUP Journal of Applied Economics, 8, 5 \& 6, 65-72

Qazizada, W., \& Stockhammer, E. (2015). Government spending multipliers in contraction and expansion. International Review of Applied Economics, 29(2), 238-258.

Tang, T. (2004). A reassessment of aggregate import demand function in the ASEAN-5: a cointegration analysis. The International Trade Journal, 18(3), 239-268.

Tang, T. C., \& Nair, M. (2002). A cointegration analysis of Malaysian import demand function: reassessment from the bounds test. Applied Economics Letters, 9(5), 293-296.

Tsionas, E. G., \& Christopoulos, D. K. (2004). International evidence on import demand. Empirica, 31(1), 43-53.

Yin, F., \& Hamori, S. (2011). Estimating the import demand function in the autoregressive distributed lag framework: the case of China. Economics bulletin, 31(2), 1576-1591.

Yoon, I. H., \& Kim, Y. M. (2019). Estimating Import Demand Function for the United States. Asia-Pacific Journal of Business, 10(2), 13-26. 